\title{
Evaluation of a novel radiofolate in tumour-bearing mice: promising prospects for folate-based radionuclide therapy
}

\author{
Cristina Müller • Thomas L. Mindt • Marion de Jong • \\ Roger Schibli
}

Received: 12 September 2008 / Accepted: 10 December 2008 / Published online: 30 January 2009

(C) Springer-Verlag 2009

\begin{abstract}
Purpose Folate-based radiopharmaceuticals have the potential to be used for imaging and therapy of tumours positive for the folate receptor (FR). We describe the in vitro and in vivo evaluation of a DOTA-folate conjugate. Methods Radiolabelling of the DOTA-folate was carried out via standard procedures using ${ }^{111} \mathrm{InCl}_{3}$ and ${ }^{177} \mathrm{LuCl}_{3}$, respectively. The distribution coefficient $(\log \mathrm{D})$ was determined in octanol/PBS ( $\mathrm{pH}$ 7.4). Tissue distribution was investigated in nude mice bearing $\mathrm{KB}$ tumour xenografts at different time points after administration of ${ }^{111}$ In-DOTA-folate (radiofolate 1) or ${ }^{177}$ Lu-DOTA-folate (radiofolate 2) (1 MBq, $1 \mathrm{nmol}$ per mouse). Pemetrexed (PMX, $400 \mu \mathrm{g}$ ) was injected $1 \mathrm{~h}$ prior to the radiofolate in order to reduce renal uptake. Images were acquired with a SPECT/CT camera $24 \mathrm{~h}$ after injection of the radiofolate (40-50 MBq, 3 nmol per mouse).

Results The hydrophilic character of the DOTA-folate was represented by a low $\log \mathrm{D}$ value (radiofolate $1-4.21 \pm 0.11$ ). In vivo, maximal tumour uptake was found $4 \mathrm{~h}$ after injection (radiofolate $15.80 \pm 0.55 \% \mathrm{ID} / \mathrm{g}$; radiofolate 2 $7.51 \pm 1.25 \% \mathrm{ID} / \mathrm{g}$ ). In FR-positive kidneys there was considerable accumulation of the radiofolates (radiofolate
\end{abstract}

C. Müller $(\bowtie) \cdot$ R. Schibli

Center for Radiopharmaceutical Science ETH-PSI-USZ,

Paul Scherrer Institute,

5232 Villigen PSI, Switzerland

e-mail: cristina.mueller@psi.ch

C. Müller $\cdot$ M. de Jong

Department of Nuclear Medicine, Erasmus MC,

3015 CE Rotterdam, The Netherlands

T. L. Mindt $\cdot$ R. Schibli

Department of Chemistry and Applied Biosciences, ETH Zurich,

8093 Zurich, Switzerland
$155.88 \pm 3.91 \% \mathrm{ID} / \mathrm{g}$; radiofolate $257.22 \pm 11.05 \% \mathrm{ID} / \mathrm{g}$; $4 \mathrm{~h}$ after injection). However, renal uptake was reduced by preinjection of PMX (radiofolate 1 9.52 $\pm 1.07 \% \mathrm{ID} / \mathrm{g}$; radiofolate $213.43 \pm 0.54 \% \mathrm{ID} / \mathrm{g} ; 4 \mathrm{~h}$ after injection) whereas the tumour uptake was retained (radiofolate 1 $6.32 \pm 0.41 \% \mathrm{ID} / \mathrm{g}$; radiofolate $28.99 \pm 0.43 \% \mathrm{ID} / \mathrm{g} ; 4 \mathrm{~h}$ after injection). SPECT/CT images clearly confirmed favourable tissue distribution of the novel radiofolates and the positive effect of PMX.

Conclusion The preliminary requirements for the therapeutic use of the novel DOTA-folate are met by its favourable tissue distribution that can be ascribed to its hydrophilic properties and combined administration with PMX.

Keywords DOTA-folate - Pemetrexed - Folate receptor . SPECT/CT $\cdot{ }^{177} \mathrm{Lu}$

\section{Introduction}

The folate receptor (FR) is a promising target for imaging and therapy of cancer and inflammatory diseases because of its frequent overexpression in tumour cells (epithelial cancers of the ovary, kidney, colon, lung etc. [1-4]) and activated macrophages [5], but limited expression in normal tissues and organs, and also because of its high affinity for folic acid $\left(\mathrm{K}_{\mathrm{D}}<10^{-9} M\right)$ even in its conjugated state that allows the use of this vitamin as a molecular "Trojan Horse" to carry conjugated probes into FR-positive pathological cells.

Folate-based conjugates of several radionuclides $\left({ }^{99 \mathrm{~m}} \mathrm{Tc}\right.$ [6-11], ${ }^{111}$ In [7, 12], ${ }^{66 / 67 / 68} \mathrm{Ga}[13,14]$ and $\left.{ }^{18} \mathrm{~F}[15]\right)$ for SPECT and PET imaging purposes have been developed and successfully evaluated in preclinical and clinical studies $[16,17]$. For therapeutic purposes, the FR has been 
exploited using folic acid conjugates with a variety of cargoes such as chemotherapeutics [18], liposomes with entrapped drugs [19], oligonucleotides and genes [20], and haptens for FR-targeted immunotherapy [21, 22]. In particular the number of folic acid-targeted small molecular weight chemotherapeutics has increased rapidly. Administration of folate conjugates of mitomycin C [23], maytansinoid [24] and vinca alkaloids $[25,26]$ has been shown to result in effective tumour cell regression in preclinical studies in vitro and in tumour (xeno)grafted mice. These promising results led to the investigation of folic acid-targeted chemotherapeutics in phase 1 and 2 clinical trials.

Folate-based radiotherapy, however, has not been envisaged until now because significant and FR-specific uptake of radiofolates in the kidneys $[8,10,11,27]$ involves the risk of radionephrotoxicity. Small molecular weight folate radiopharmaceuticals encounter the same fate as folates that are filtered in the glomeruli and reabsorbed from primary urine via FRs located in the proximal tubule cells of the renal tissue [28-32]. In a clinical trial with ${ }^{111}$ In-DTPAfolate a similar tissue distribution of radioactivity was detected in patients as previously found in mice including a significant radiofolate uptake in the kidneys [12]. Thus, the mouse serves as a useful animal model for predicting the tissue distribution of folate-based radiopharmaceuticals in humans. In a comparative study, Parker et al. investigated the FR expression levels in organs and tissues of different species [4]. They demonstrated that the density of FRs in human kidneys most closely resembles that in mice.

During our research developing and evaluating radiofolates, we have discovered that undesired kidney uptake is significantly reduced when the antifolate pemetrexed (PMX, Alimta) is injected shortly before the radiofolate $[33,34]$. PMX is a multitargeted antifolate that has demonstrated promising clinical activity in a wide variety of solid tumours, in particular in mesothelioma and nonsmall-cell lung cancer, but also in cancer of the bladder, cervix, colorectum, head and neck etc. [35, 36]. The "antifolate effect" was discovered using our organometallic ${ }^{99 \mathrm{~m}} \mathrm{Tc} /{ }^{188} \mathrm{Re}$-radiofolate tracers $[33,37,38]$ and was corroborated with other radiofolates, such as the clinically tested ${ }^{111}$ In-DTPA-folate [12]. Based on these results, we proposed a general validity of the effect of PMX on renal uptake of radiofolates independent of the radiofolate ligand, the chelating system and the radiometal, respectively. Although we hypothesize that, due to their structural similarities, radiofolates and PMX interact and compete for FR binding in the proximal tubule cells of the kidneys, the exact mechanism of our observation has not been elucidated yet and is still the subject of current investigations.

The folate conjugate used in this study comprised a DOTA chelator suitable for coordination with a variety of diagnostic radionuclides (e.g. ${ }^{111} \mathrm{In},{ }^{67 / 68} \mathrm{Ga},{ }^{64} \mathrm{Cu}$ ) and therapeutic radionuclides (e.g. ${ }^{177} \mathrm{Lu},{ }^{67} \mathrm{Cu},{ }^{90} \mathrm{Y}$ ). We describe here the evaluation of DOTA-folate radiolabelled with ${ }^{111} \mathrm{In}$ and ${ }^{177} \mathrm{Lu} .{ }^{111} \mathrm{In}$ is a diagnostic radionuclide with $\gamma$ energies $(171 \mathrm{keV}, 245 \mathrm{keV})$ ideal for SPECT imaging purposes and thus is frequently used in diagnostic nuclear medicine. ${ }^{177} \mathrm{Lu}$ is a radiolanthanide that emits $\beta$ radiation $(490 \mathrm{keV})$ with a tissue penetration range appropriate for treatment of small tumours and metastases. The low $\beta$ energy together with its long half-life (6.7 days) make it a promising isotope for radiopharmaceutical treatment of solid tumours as demonstrated in a number of clinical applications [39-41]. In addition, ${ }^{177} \mathrm{Lu}$ emits $\gamma$ radiation (113 keV, $210 \mathrm{keV}$ ) detectable by SPECT, allowing physicians to use it for monitoring therapy.

The aim of this study was to test and evaluate the novel DOTA-folate in vitro and in vivo. The use of an established FRpositive KB tumour xenografted mouse model allowed comparison with previously developed radiofolates. Biodistribution studies and imaging studies were performed with ${ }^{111} \mathrm{In}$ - and ${ }^{177}$ Lu-radiolabelled DOTA-folate (radiofolates 1 and 2, respectively) alone and in combination with PMX for selective reduction of radiofolate uptake in the kidneys. The results were compared with those of our previously evaluated radiofolates and discussed in relation to their potential use for therapeutic purposes.

\section{Materials and methods}

Synthesis of the DOTA-folate conjugate

The DOTA-folate ligand (Fig. 1) was prepared by the $\mathrm{Cu}$ (I)-catalysed [3+2] cycloaddition of azides and terminal alkynes, a transformation which has been denoted as a "click reaction" [42, 43]. The use of click chemistry for
Fig. 1 Chemical structure of the DOTA-folate ligand

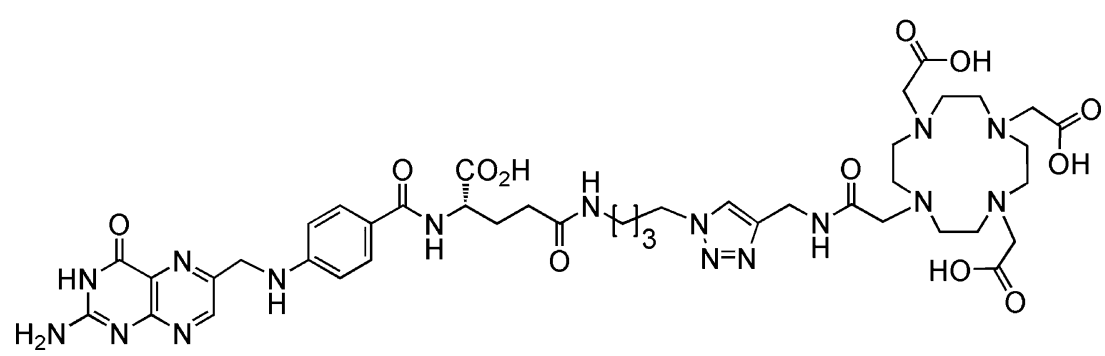


conjugation of the DOTA-chelator to other biomolecules has been reported [44, 45]. In brief, $\mathrm{Cu}(\mathrm{I})$-catalysed reaction of folic acid- $\gamma$-(4-azido)-butaneamide [46] with an alkyne derivatized DOTA-chelator yielded under optimized reaction conditions the DOTA-folate ligand in good yield (45\% yield for three steps; purity $>98 \%$ ) after purification by HPLC (high-resolution MS data: $\mathrm{m} / \mathrm{z}$ $\left([\mathrm{M}+\mathrm{Na}]^{+}\right.$calculated for $\mathrm{C}_{42} \mathrm{H}_{58} \mathrm{~N}_{16} \mathrm{O}_{12} \mathrm{Na}$ : 1001.4318, found 1001.4308). Details of the synthetic procedures will be described elsewhere.

\section{Radiolabelling}

A stock solution $(10 \mu \mathrm{l})$ of the DOTA-folate ligand $\left(10^{-3} \mathrm{M}\right)$ was added to $250 \mu \mathrm{l}$ sodium acetate buffer, $0.4 \mathrm{M}$, pH 5 . Then, radioactivity $\left({ }^{111} \mathrm{InCl}_{3}\right.$, Mallinckrodt-Tyco, Petten, The Netherlands, or ${ }^{177} \mathrm{LuCl}_{3}$, Nuclear Research and Consultancy Group, NRG, Petten, The Netherlands) was added (10-370 MBq) and the reaction solution was heated for $30 \mathrm{~min}$ at $90^{\circ} \mathrm{C}$. DTPA $\left(10 \mu \mathrm{l}, 10^{-3} \mathrm{M}\right)$ was added for complexation of potential traces of unreacted ${ }^{111} \mathrm{In}$ or ${ }^{177} \mathrm{Lu}$. Quality control was performed by HPLC which revealed a radiochemical purity of $>90 \%$. The HPLC system comprised a Waters system with a tunable absorbance detector and a Unispec multichannel analyser $\gamma$-detector and a Waters Symmetry C-18 reversed-phase column $(5 \mathrm{~mm}$, $25 \mathrm{~cm} \times 4.6 \mathrm{~mm}$ ) with an eluent that consisted of aqueous $0.05 M$ triethylammonium phosphate buffer, $\mathrm{pH} 2.25$, and methanol with a linear gradient to $80 \%$ methanol over $30 \mathrm{~min}$. The highest specific activity $(37 \mathrm{MBq} / \mathrm{nmol})$ tested resulted in a radiochemical purity of $92 \%$. For the biodistribution studies the radiolabelling was performed at low specific activity $(1 \mathrm{MBq} / \mathrm{nmol})$ allowing a radiochemical purity of $98 \%$. The remaining amount of radioactivity $(<10 \%)$ was determined to be free ${ }^{111} \mathrm{In}$ and ${ }^{177} \mathrm{Lu}$ complexed by the DTPA that had been added. For in vitro cell experiments radiofolate 1 was separated from unlabelled DOTA-folate by HPLC diluted in phosphate buffered saline (PBS) to a radioactivity concentration of $1.7 \mathrm{MBq} / \mathrm{ml}$ (PBS; pH 7.4). For in vivo studies radiotracers 1 and 2 were used without separation from unlabelled DOTA-folate. Radiofolates 1 and 2 were diluted with $\mathrm{NaCl} 0.9 \%$ to the desired specific activity $(1 \mathrm{MBq}, 1 \mathrm{nmol}$ per mouse for biodistribution studies; $40-50 \mathrm{MBq}, 3 \mathrm{nmol}$ per mouse for SPECT imaging) for immediate administration to the mice.

Determination of the octanol/PBS distribution coefficient $(\log \mathrm{D})$

For comparison of the hydrophilic/lipophilic character, the distribution coefficient ( $\log$ D) of radiofolate 1 was determined by a procedure published in the literature [47]. In brief, a sample of HPLC-purified radiofolate $1(150 \mathrm{kBq})$ was mixed with equal amounts $(1.5 \mathrm{ml})$ of PBS (pH 7.4) and octanol. The resulting biphasic system was mixed vigorously for $1 \mathrm{~min}$ and the two phases were separated by centrifugation for $5 \mathrm{~min}$. Aliquots of $0.5 \mathrm{ml}$ were taken from each layer and counted for radioactivity in a $\gamma$-counter. The distribution coefficient was expressed as the ratio of counts per minute measured in the octanol phase to the counts per minute measured in the PBS phase. The results represent the mean $( \pm \mathrm{SD})$ of six measurements for each compound.

\section{Cell culture}

KB cells (human nasopharyngeal carcinoma cell line; CCL-17) were purchased from American Type Culture Collection (ATCC, Manassas, VA). The cells were cultured as monolayers at $37^{\circ} \mathrm{C}$ in a humidified atmosphere containing $5 \% \mathrm{CO}_{2}$. Importantly, the cells were cultured in a folate-free cell culture medium, FFRPMI (modified RPMI, without folic acid, vitamin $\mathrm{B}_{12}$ and phenol red; Cell Culture Technologies, Gravesano/Lugano, Switzerland). FFRPMI medium was supplemented with $10 \%$ heat-inactivated fetal calf serum (FCS, as the only source of folate), L-glutamine and antibiotics (penicillin/streptomycin/fungizone). Routine culture treatment was performed twice a week with EDTA ( $2.5 \mathrm{mmol} / \mathrm{l})$ in PBS.

In vitro cell studies

KB cells were seeded in 12 -well plates $\left(7.5 \times 10^{5}\right.$ cells/well $)$ $18 \mathrm{~h}$ prior to the experiment to form confluent monolayers overnight. For all of the in vitro studies we used radiofolate 1. All experiments were performed in triplicate.

Time-dependent uptake of ${ }^{111}$ In-DOTA-folate Cell monolayers were rinsed with PBS ( $\mathrm{pH}$ 7.4). Pure FFRPMI medium (without FCS/L-glutamine/antibiotics, $975 \mu \mathrm{l}$ ) was added into each well. Blocking studies were performed with FFRPMI medium $(475 \mu \mathrm{l})$ and a folic acid solution $(200 \mu M, 500 \mu \mathrm{l})$. The well plates were preincubated at $37^{\circ} \mathrm{C}$ for $45 \mathrm{~min}$. A solution of the radiofolate tracer $(25 \mu \mathrm{l}$, $1.5 \mathrm{MBq} / \mathrm{ml}$ ) was added to each well and the well plates were incubated for $0,5,15,30,60,120$ and $240 \mathrm{~min}$ at $37^{\circ} \mathrm{C}$. The supernatants were removed and the monolayers washed several times. Radioactivity counted in samples washed with only PBS could be ascribed to the sum of FR-bound radiotracer on the cell surface plus the internalized fraction. Cell samples washed with stripping buffer (an aqueous solution of $0.1 \mathrm{M}$ acetic acid and $0.15 M \mathrm{NaCl}, \mathrm{pH} 3$ ) in order to release radiotracers from FRs on the cell surface enabled determination of the internalized fraction of radioactivity [48, 49].

Uptake of ${ }^{111}$ In-DOTA-folate in combination with PMX The experiment was performed as described above. PMX was 
added in different concentrations $(0-10 \mu M)$ and the well plates were incubated at $37^{\circ} \mathrm{C}$ for $45 \mathrm{~min}$. After addition of the radiofolate, the well plates were incubated at $37^{\circ} \mathrm{C}$ for another $2 \mathrm{~h}$. Then, each well was washed tree times with ice-cold PBS, pH 7.4. The monolayers were lysed in $1 \mathrm{~N}$ $\mathrm{NaOH}(1 \mathrm{ml})$, transferred to 4-ml tubes, and homogenized by vortexing. The radioactivity of each sample was measured with a $\gamma$-counter (Wizard, 1480, Perkin Elmer). The concentration of proteins was determined for each sample in order to normalize measured radioactivity of the samples with respect to the averaged sample protein content that accounted for $0.5 \mathrm{mg}$ protein per well. The raw data were converted from counts per minute into percentage of total radioactivity added to each well.

\section{Biodistribution studies}

All animal experiments were approved by the governing Animal Welfare Committee and conducted in accordance with the regulations of the Erasmus Medical Center, Rotterdam, The Netherlands. Female athymic nude mice (NMRI nu/nu) at 6-8 weeks of age were purchased from Charles River Laboratories (Maastricht, The Netherlands). The animals were fed with a folate-deficient rodent diet starting 5 days prior to tumour cell inoculation [50]. Mice were inoculated with $\mathrm{KB}$ cells $\left(5 \times 10^{6}\right.$ cells in $\left.100 \mu \mathrm{PBS}\right)$ into the subcutis of each shoulder. Animal experiments were performed approximately 14 days after tumour cell inoculation, when the tumour had reached a size of approximately $0.5-1.5 \mathrm{~cm}^{3}$.

Biodistribution studies were performed in triplicate. Radiofolates 1 and 2 were administered to the mice in a volume of $100 \mu \mathrm{l}$ via a lateral tail vein. PMX (Alimta, LY231514; Eli Lilly, Bad Homburg, Germany) was diluted with $\mathrm{NaCl} 0.9 \%$ according to the instructions of the manufacturer and injected into a lateral tail vein $(400 \mu \mathrm{g}$ in $100 \mu \mathrm{l}), 1 \mathrm{~h}$ prior to the radiotracer. Blocking studies were performed with excess folic acid dissolved in PBS $(100 \mu \mathrm{g} / 100 \mu \mathrm{l})$ and intravenously injected immediately before the radiotracer. The animals were killed at $1 \mathrm{~h}, 4 \mathrm{~h}$, $24 \mathrm{~h}$ or $48 \mathrm{~h}$ after administration of radiofolate 1 or 2 alone or with either preinjected PMX or coinjected folic acid. Selected tissues and organs were collected, weighed, and counted for radioactivity in a $\gamma$-counter (Wizard, 1480, Perkin Elmer). The results were recorded as percentage of the injected dose per gram of tissue $(\% \mathrm{ID} / \mathrm{g})$, using reference counts from a definite sample of the original injectate that was counted at the same time. Statistical analyses were performed using a $t$-test (Microsoft Excel software). All analyses were two-tailed and considered as type 3 (two sample unequal variance). A $p$-value of $<0.05$ was considered statistically significant.

\section{SPECT/CT imaging}

SPECT scans were performed with a four-headed multiplexing multipinhole camera (NanoSPECT/CT; Bioscan, Washington DC) [51]. Each head was equipped with tungsten-based collimator of nine 1.4-mm diameter pinholes, imaging a cylindrical field of view $37 \mathrm{~mm}$ in diameter and $16 \mathrm{~mm}$ in length. The axial field of view was extended using a step-and-shoot helical (SPECT) or continuous (CT) acquisition mode with the user defining a range of 16-230 $\mathrm{mm}$ according to the region to be imaged. The acquisitions in mice bearing subcutaneous KB tumours were performed $24 \mathrm{~h}$ after injection of radiofolate 1 and 2 . The time per view was chosen as $120-150 \mathrm{~s}$, resulting in a total scan duration of approximately $60 \mathrm{~min}$. CT scans were performed with an integrated CT scanner using a tube voltage of $45 \mathrm{kV}$ and an exposure time of $1500 \mathrm{~ms}$ per view. After acquisition, SPECT data were reconstructed iteratively with HiSPECT software (Scivis). The CT reconstruction used cone-beam filtered back-projection. SPECT and CT data were automatically coregistered as both modalities shared the same axis of rotation. The fused datasets were analysed with InVivoScope (Bioscan) postprocessing software.

\section{Results}

Determination of $\log \mathrm{D}$ values

The octanol/PBS (pH 7.4) distribution coefficients (log D values) were determined with radiofolate 1 and two organometallic ${ }^{99 \mathrm{~m}} \mathrm{Tc}$ radiofolates that had been evaluated previously in our laboratories (Table 1). For the novel radiofolate 1 we determined a $\log \mathrm{D}$ value of $-4.21 \pm 0.11$, a value significantly lower than that determined for the ${ }^{99 \mathrm{~m}} \mathrm{Tc}$ radiofolates. These results indicate the desired increase in hydrophilicity of radiofolate 1 compared to the organometallic ${ }^{99 \mathrm{~m}} \mathrm{Tc}$ radiofolates.

In vitro cell experiment

In vitro cell binding experiments were performed with DOTA-folate radiolabelled with ${ }^{111} \mathrm{In}$. FR-specific binding of the radiofolate was proved by an experiment with excess

Table 1 Octanol/PBS ( $\mathrm{pH}$ 7.4) distribution coefficients ( $\log \mathrm{D}$ values)

\begin{tabular}{ll}
\hline Folate radiotracer & Log D \\
\hline${ }^{111} \mathrm{In}$-DOTA-folate & $-4.21 \pm 0.11$ \\
${ }^{99 \mathrm{~m}} \mathrm{Tc}(\mathrm{CO})_{3}$-His-folate & $-3.47 \pm 0.05$ \\
${ }^{99 \mathrm{~m}} \mathrm{Tc}(\mathrm{CO})_{3}$-PAMA-folate & $-2.12 \pm 0.01$ \\
\hline
\end{tabular}

The values are the averages \pm SD of six experiments. 
cold folic acid that resulted in an almost complete blockade of radiofolate uptake $(<0.5 \%$ cell binding of total added radioactivity). The time-dependent experiment showed a constantly increasing cellular uptake of radiofolate 1 until steady state was reached after $2 \mathrm{~h}$ at $37^{\circ} \mathrm{C}$. The internalized fraction of radiofolate 1 accounted for $25-30 \%$ of total cell uptake (sum of FR-bound radiofolate on the cell surface and internalized fraction). The time course of the cellular uptake of radiofolate 1 was largely comparable to the results found with organometallic ${ }^{99 \mathrm{~m}} \mathrm{Tc}$ radiofolates as previously reported by our group [10].

Cell experiments in combination with PMX showed that PMX does not influence radiofolate 1 uptake over a concentration range up to $1 \mu M$. Only a PMX concentration of $10 \mu M$ led to a marked reduction in radiofolate uptake to approximately $50 \%$ of controls (Fig. 2).

\section{Biodistribution studies}

Biodistribution studies of radiofolates 1 and 2 were carried out under conditions important for potential therapeutic use. In vivo evaluation was performed in athymic nude mice bearing KB tumour xenografts, the standard animal model for FR-targeting studies.

The results of the tissue distribution of radiofolates 1 and 2 are presented in Tables 2 and 3. The tumour uptake was highest $4 \mathrm{~h}$ after injection (radiofolate $15.80 \pm 0.55 \% \mathrm{ID} / \mathrm{g}$; radiofolate $27.51 \pm 1.25 \% \mathrm{ID} / \mathrm{g}$ ) and almost completely retained over the time of investigation. The radiofolates were quickly cleared from the blood stream and only negligible amounts of radioactivity were found in the lungs, spleen, stomach, muscle and bones. However, in the liver a relatively high accumulation of radioactivity was observed at early time points (radiofolate $15.20 \pm 2.00 \% \mathrm{ID} / \mathrm{g}$;

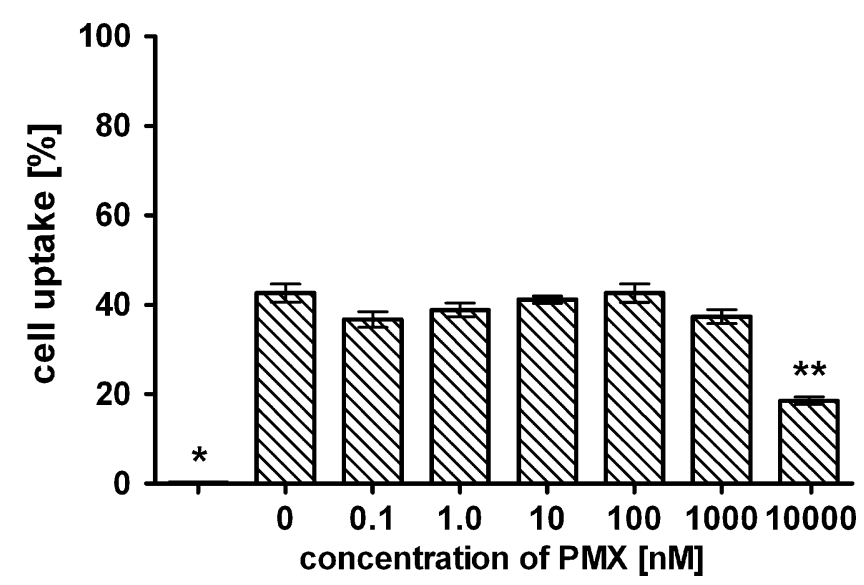

Fig. 2 Uptake of radiofolate 1 in $\mathrm{KB}$ tumour cells pre-/coincubated with different concentrations of PMX. The cell uptake was calculated per $0.5 \mathrm{mg}$ protein and is indicated as percentage of total added radioactivity. *Nonspecific binding after addition of excess folic acid $(<0.5 \%)$; ** significantly reduced cell uptake with $10 \mu M$ PMX radiofolate $24.63 \pm 1.12 \% \mathrm{ID} / \mathrm{g} ; 4 \mathrm{~h}$ after injection), that decreased over time. In the kidneys, very high accumulation of radioactivity (about $57 \% \mathrm{ID} / \mathrm{g}, 4 \mathrm{~h}$ after injection) was found for both radiofolates 1 and 2 . It is noteworthy that the tumour-to-kidney ratios were very low at all time points investigated (radiofolate $1<0.12$; radiofolate $2<0.16$ ). Besides the kidneys and tumours, FR-specific accumulation was found in the salivary glands. The highest uptake in the salivary glands was found shortly after injection of the radiofolates, but radioactivity accumulation decreased over the time of investigation. Importantly, preinjection of the antifolate PMX led to a significant improvement in the overall tissue distribution of the radiofolates. In FR-positive kidneys a significant reduction in radioactivity uptake $(p<0.05)$ was found after injection of PMX. Also in the salivary glands uptake was slightly reduced in mice that received PMX. Tumour uptake, on the other hand, was not impaired by PMX (radiofolate $16.32 \pm 0.41 \% \mathrm{ID} / \mathrm{g}$; radiofolate $28.99 \pm 0.43 \% \mathrm{ID} / \mathrm{g}, 4 \mathrm{~h}$ after injection). Thus, after injection of PMX, the tumour-to-kidney ratio was increased sevenfold for radiofolate 1 and fivefold for radiofolate 2 .

\section{SPECT/CT imaging}

Imaging experiments were performed with a high-resolution/ high-sensitivity small-animal SPECT/CT camera. Mice were injected with radiofolate 1 or $2(40-50 \mathrm{MBq})$ with or without preinjection of PMX. Whereas ${ }^{99 \mathrm{~m}} \mathrm{Tc}$ radiofolates and ${ }^{111}$ In-radiofolates have been successfully used for SPECT imaging studies in our previous work [34, 52], this was the first time that SPECT/CT had been performed with a ${ }^{177} \mathrm{Lu}$-radiolabelled folate conjugate.

Figure 3 shows a SPECT/CT scan of a mouse $24 \mathrm{~h}$ after injection of radiofolate 2 as a control and a mouse that had been injected with PMX $1 \mathrm{~h}$ before radioactivity administration. Both mice showed radioactivity accumulation in FR-positive KB-tumour xenografts located on each shoulder. Whereas radioactivity accumulation in the renal tissue of the control mouse was very high (Fig. 3a), a considerable reduction in radioactivity uptake was seen in the kidneys of the mouse that received PMX (Fig. 3b). The same experiment performed with radiofolate 1 showed similar results (data not shown). It has to be mentioned that the higher amount of DOTA-folate (3 nmol per mouse) used for SPECT/CT scans compared to the amount used for biodistribution studies ( $1 \mathrm{nmol}$ per mouse) resulted in a slightly reduced radiofolate uptake in normal tissues and organs (e.g. salivary glands).

\section{Discussion}

In our previous work we have developed organometallic radiofolates for potential use in diagnostic $\left({ }^{99 \mathrm{~m}} \mathrm{Tc}, \gamma\right.$ - 
Table 2 Biodistribution of radiofolate 1 in KB tumour-bearing female nude mice expressed as \% ID/g.

\begin{tabular}{|c|c|c|c|c|c|c|c|}
\hline \multirow[t]{3}{*}{ Tissue } & \multicolumn{7}{|c|}{ Time after radiofolate 1 injection } \\
\hline & \multirow[t]{2}{*}{$1 \mathrm{~h}$} & \multirow[t]{2}{*}{$4 \mathrm{~h}$} & \multirow[t]{2}{*}{$24 \mathrm{~h}$} & \multirow[t]{2}{*}{$4 h^{a}$} & \multicolumn{3}{|c|}{ With preinjected $\mathrm{PMX}^{\mathrm{a}}$} \\
\hline & & & & & $1 \mathrm{~h}$ & $4 \mathrm{~h}$ & $24 \mathrm{~h}$ \\
\hline Blood & $0.20 \pm 0.09$ & $0.08 \pm 0.02$ & $0.06 \pm 0.02$ & $0.02 \pm 0.00$ & $0.19 \pm 0.06$ & $0.07 \pm 0.01$ & $0.04 \pm 0.01$ \\
\hline Lung & $0.86 \pm 0.14$ & $0.70 \pm 0.06$ & $0.62 \pm 0.03$ & $0.05 \pm 0.00$ & $0.76 \pm 0.05$ & $0.62 \pm 0.22$ & $0.42 \pm 0.01$ \\
\hline Spleen & $0.31 \pm 0.05$ & $0.30 \pm 0.09$ & $0.16 \pm 0.04$ & $0.06 \pm 0.01$ & $0.22 \pm 0.07$ & $0.19 \pm 0.01$ & $0.18 \pm 0.02$ \\
\hline Kidneys & $46.34 \pm 5.18$ & $55.88 \pm 3.91$ & $43.55 \pm 6.69$ & $3.53 \pm 1.18$ & $10.52 \pm 2.46$ & $9.52 \pm 1.07$ & $8.56 \pm 1.00$ \\
\hline Stomach & $1.85 \pm 0.36$ & $1.70 \pm 0.31$ & $1.55 \pm 0.35$ & $0.04 \pm 0.00$ & $1.39 \pm 0.34$ & $1.49 \pm 0.25$ & $1.24 \pm 0.28$ \\
\hline Intestines & $0.55 \pm 0.05$ & $0.43 \pm 0.06$ & $0.35 \pm 0.03$ & $0.09 \pm 0.00$ & $0.50 \pm 0.11$ & $0.63 \pm 0.38$ & $0.48 \pm 0.32$ \\
\hline Liver & $6.95 \pm 2.67$ & $5.20 \pm 2.00$ & $2.23 \pm 0.64$ & $0.26 \pm 0.06$ & $3.90 \pm 0.48$ & $1.96 \pm 0.44$ & $1.10 \pm 0.26$ \\
\hline Salivary glands & $5.29 \pm 0.48$ & 6. $13 \pm 1.84$ & $3.17 \pm 0.98$ & $0.10 \pm 0.03$ & $3.75 \pm 0.66$ & $3.54 \pm 0.37$ & $2.33 \pm 0.20$ \\
\hline Muscle & $0.78 \pm 0.10$ & $0.61 \pm 0.10$ & $0.60 \pm 0.08$ & $0.01 \pm 0.00$ & $0.55 \pm 0.10$ & $0.67 \pm 0.14$ & $0.40 \pm 0.06$ \\
\hline Bone & $0.60 \pm 0.09$ & $0.53 \pm 0.03$ & $0.40 \pm 0.09$ & $0.03 \pm 0.01$ & $0.36 \pm 0.10$ & $0.49 \pm 0.17$ & $0.40 \pm 0.05$ \\
\hline Tumour & $4.41 \pm 1.22$ & $5.80 \pm 0.55$ & $4.85 \pm 0.95$ & $0.31 \pm 0.01$ & $6.11 \pm 1.11$ & $6.32 \pm 0.41$ & $6.28 \pm 0.93$ \\
\hline Tumour-to-blood & $23.62 \pm 4.10$ & $71.81 \pm 20.83$ & $92.96 \pm 28.93$ & & $32.59 \pm 7.06$ & $93.52 \pm 16.79$ & $142.52 \pm 9.93$ \\
\hline Tumour-to-liver & $0.65 \pm 0.12$ & $1.33 \pm 0.61$ & $2.23 \pm 0.41$ & & $0.60 \pm 0.15$ & $3.34 \pm 0.74$ & $5.99 \pm 1.95$ \\
\hline Tumour-to-kidney & $0.09 \pm 0.02$ & $0.10 \pm 0.01$ & $0.11 \pm 0.02$ & & $0.57 \pm 0.27$ & $0.67 \pm 0.09$ & $0.75 \pm 0.18$ \\
\hline
\end{tabular}

${ }^{\mathrm{a}} 100 \mu \mathrm{g}$ folic acid, injected $5 \mathrm{~min}$ before the radiotracer.

${ }^{\mathrm{b}} 400 \mu \mathrm{g}$, injected $1 \mathrm{~h}$ before the radiotracer.

radiation) and therapeutic ( ${ }^{188} \mathrm{Re}, \beta$-radiation) nuclear medicine. The evaluation of these radiofolates in tumourbearing mice revealed specific accumulation in FR-positive tumours and kidneys. However, we found unfavourably high background radiation in the abdomen as a result of the hepatobiliary excretion of these compounds, presumably due to the lipophilic tricarbonyl core. High background radiation would prevent the detection of small lesions in the abdomen and even more problematic, a high activity dose burden caused by therapeutic radiation would damage healthy organs and tissues. Therefore, it is generally desirable to develop hydrophilic radiopharmaceuticals that are largely excreted via the kidneys. Kidneys are radiationsensitive organs, but there are effective methods routinely used in the clinic for kidney protection such as, for example, infusion of amino acids [53, 54].

In the case of folate-based radiopharmaceuticals, high kidney uptake is a consequence of specific binding to FRs

Table 3 Biodistribution of radiofolate 2 in KB tumour-bearing female nude mice expressed as \% ID/g.

\begin{tabular}{|c|c|c|c|c|c|c|c|c|}
\hline \multirow[t]{3}{*}{ Tissue } & \multicolumn{8}{|c|}{ Time after radiofolate 2 injection } \\
\hline & \multirow[t]{2}{*}{$1 \mathrm{~h}$} & \multirow[t]{2}{*}{$4 \mathrm{~h}$} & \multirow[t]{2}{*}{$24 \mathrm{~h}$} & \multirow[t]{2}{*}{$48 \mathrm{~h}$} & \multicolumn{4}{|c|}{ With preinjected $\mathrm{PMX}^{\mathrm{a}}$} \\
\hline & & & & & $1 \mathrm{~h}$ & $4 \mathrm{~h}$ & $24 \mathrm{~h}$ & $48 \mathrm{~h}$ \\
\hline Blood & $0.12 \pm 0.02$ & $0.06 \pm 0.03$ & $0.03 \pm 0.01$ & $0.02 \pm 0.01$ & $0.17 \pm 0.06$ & $0.03 \pm 0.00$ & $0.03 \pm 0.02$ & $0.02 \pm 0.00$ \\
\hline Lung & $0.91 \pm 0.01$ & $0.75 \pm 0.10$ & $0.53 \pm 0.14$ & $0.43 \pm 0.13$ & $0.81 \pm 0.10$ & $0.49 \pm 0.06$ & $0.39 \pm 0.11$ & $0.31 \pm 0.06$ \\
\hline Spleen & $0.30 \pm 0.04$ & $0.28 \pm 0.05$ & $0.20 \pm 0.02$ & $0.11 \pm 0.01$ & $0.30 \pm 0.08$ & $0.16 \pm 0.01$ & $0.14 \pm 0.02$ & $0.11 \pm 0.01$ \\
\hline Kidneys & $47.06 \pm 3.17$ & $57.22 \pm 11.05$ & $45.10 \pm 1.21$ & $42.68 \pm 4.96$ & $16.13 \pm 4.42$ & $13.43 \pm 0.54$ & $11.87 \pm 1.67$ & $9.58 \pm 1.48$ \\
\hline Stomach & $1.81 \pm 0.13$ & $1.92 \pm 0.60$ & $1.26 \pm 0.06$ & $0.78 \pm 0.11$ & $1.52 \pm 0.31$ & $1.42 \pm 0.10$ & $0.96 \pm 0.10$ & $0.66 \pm 0.14$ \\
\hline Intestines & $0.52 \pm 0.07$ & $0.43 \pm 0.20$ & $0.27 \pm 0.06$ & $0.24 \pm 0.10$ & $0.49 \pm 0.16$ & $0.54 \pm 0.04$ & $0.24 \pm 0.04$ & $0.17 \pm 0.04$ \\
\hline Liver & $4.81 \pm 0.52$ & $4.63 \pm 1.12$ & $2.13 \pm 0.24$ & $1.60 \pm 0.44$ & $5.12 \pm 2.41$ & $1.87 \pm 0.01$ & $1.26 \pm 0.23$ & $0.96 \pm 0.10$ \\
\hline Salivary glands & $5.38 \pm 0.42$ & $5.02 \pm 1.07$ & $3.41 \pm 0.31$ & $2.50 \pm 0.12$ & $5.21 \pm 0.72$ & $4.01 \pm 0.22$ & $2.14 \pm 0.35$ & $1.54 \pm 0.20$ \\
\hline Muscle & $0.88 \pm 0.12$ & $0.70 \pm 0.05$ & $0.55 \pm 0.12$ & $0.33 \pm 0.10$ & $0.66 \pm 0.09$ & $0.57 \pm 0.05$ & $0.37 \pm 0.05$ & $0.28 \pm 0.02$ \\
\hline Bone & $0.56 \pm 0.05$ & $0.46 \pm 0.03$ & $0.35 \pm 0.09$ & $0.21 \pm 0.08$ & $0.49 \pm 0.07$ & $0.30 \pm 0.06$ & $0.22 \pm 0.05$ & $0.21 \pm 0.03$ \\
\hline Tumour & $7.37 \pm 0.94$ & $7.51 \pm 1.25$ & $6.78 \pm 1.87$ & $4.99 \pm 0.98$ & $8.71 \pm 0.36$ & $8.99 \pm 0.43$ & $8.61 \pm 1.36$ & $5.04 \pm 0.73$ \\
\hline Tumour-to-blood & $63.14 \pm 4.20$ & $125.07 \pm 34.59$ & $272.13 \pm 128.58$ & $277.17 \pm 183.62$ & $51.19 \pm 29.04$ & $268.61 \pm 7.33$ & $397.99 \pm 202.16$ & $266.15 \pm 31.21$ \\
\hline Tumour-to-liver & $1.54 \pm 0.23$ & $1.61 \pm 0.36$ & $3.29 \pm 1.25$ & $3.29 \pm 0.98$ & $1.60 \pm 1.25$ & $4.80 \pm 0.21$ & $7.17 \pm 2.34$ & $5.29 \pm 1.02$ \\
\hline Tumour-to-kidney & $0.16 \pm 0.03$ & $0.13 \pm 0.02$ & $0.15 \pm 0.04$ & $0.12 \pm 0.02$ & $0.51 \pm 0.32$ & $0.67 \pm 0.01$ & $0.72 \pm 0.05$ & $0.54 \pm 0.14$ \\
\hline
\end{tabular}

a $400 \mu \mathrm{g}$, injected $1 \mathrm{~h}$ before the radiotracer. 


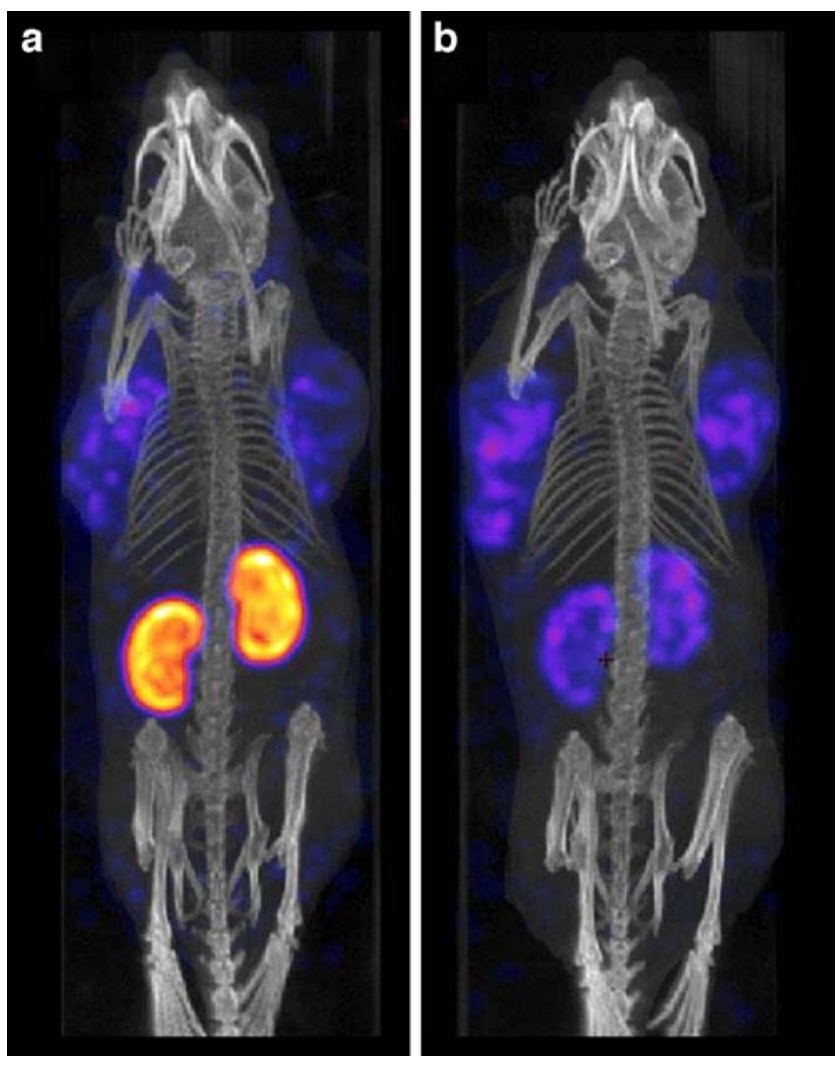

Fig. 3 Three-dimensional SPECT/CT images of KB tumour-bearing mice $24 \mathrm{~h}$ after injection of radiofolate 2: (a) control mouse and (b) mouse injected with PMX $1 \mathrm{~h}$ prior to the radiofolate

that are substantially expressed in the proximal tubule cells. A potential application of folate-based radionuclide therapy requires (1) a hydrophilic radiofolate compound that is cleared via kidneys, but at the same time (2) a method to inhibit selectively radiofolate uptake via FRs in the kidneys without affecting FR-mediated uptake in the tumour. In this study we demonstrated that both requirements can be addressed successfully by using hydrophilic folic acid radiotracers in combination with PMX.

The novel folate conjugate features a DOTA-chelator which is a polar macrocycle that allows easy radiolabelling with a variety of diagnostic (e.g. ${ }^{111} \mathrm{In},{ }^{67 / 68} \mathrm{Ga},{ }^{64} \mathrm{Cu}$ ) and therapeutic radionuclides (e.g. ${ }^{177} \mathrm{Lu},{ }^{90} \mathrm{Y},{ }^{67} \mathrm{Cu}$ ). The distribution coefficient $(\log \mathrm{D})$ of the ${ }^{111} \mathrm{In}$-radiolabelled DOTA-folate determined in octanol and PBS (pH 7.4) was favourably decreased compared to that of organometallic ${ }^{99 \mathrm{~m}} \mathrm{Tc}$ radiofolates. Finally, we successfully applied the method of preinjecting PMX previously established in our laboratory in order to reduce undesired renal retention of the novel radiofolate [33].

The in vivo evaluation was performed with radiofolates 1 and 2. It is noteworthy that biodistribution studies were performed with an amount of folate ligand that would allow the administration of a therapeutic amount of ${ }^{177} \mathrm{Lu}$ which is usually around $37 \mathrm{MBq}$ per mouse. This aspect was not considered in our previous studies with organometallic ${ }^{99 \mathrm{~m}} \mathrm{Tc} /{ }^{188} \mathrm{Re}$ radiofolates $[10,11,37]$. However, experiments in our own laboratories (unpublished data) and those in others have shown that the mass of the injected compound (e.g. folate-based or peptide-based radiopharmaceuticals) can critically affect its tissue distribution [55]. In particular in receptor-positive normal tissues and organs radioactivity accumulation is often dependent on the amount of injected targeting compound. Therefore, it is crucial to perform the evaluation studies of a therapeutically useful radiofolate under the conditions that would be applied for therapy experiments. It has to be critically acknowledged that the amount of DOTA-folate injected for the SPECT/CT imaging studies was not the same as for the biodistribution studies. A slightly lower uptake of radiofolate in normal organs (e.g. in salivary glands) in mice used for SPECT/CT scans than in mice used in biodistribution studies might have been a consequence thereof.

Not surprisingly, both radiofolate 1 and radiofolate 2 showed superior tissue distribution than our organometallic ${ }^{99 \mathrm{~m}} \mathrm{Tc}$ radiofolates $[10,11,52]$. The hydrophilic character of the DOTA-folate ligand prevented undesired excretion via the intestinal tract and therefore almost no background activity was found in the abdomen. Overall, the tissue distribution profiles of radiofolates 1 and 2 were largely comparable to that of the clinically tested ${ }^{111}$ In-DTPAfolate [34]. As expected, radioactivity uptake $(\% \mathrm{ID} / \mathrm{g})$ in the kidney was much higher than the uptake in the tumour xenografts. This situation is disadvantageous for a potential therapeutic application. However, we were able to show that preadministration of PMX resulted in a significant reduction in renal radioactivity accumulation that improved tumour-to-kidney ratios significantly. In vitro, we were able to demonstrate that concentrations up to $1 \mu M$ PMX did not affect the uptake of radiofolate 1 into cancer cells indicating that PMX and radiofolates do not compete for the same binding sites in tumour cells. On the other hand, it remains unclear whether the reduction in radiofolate uptake in the kidneys after PMX injection was based on a blockade of the FRs by PMX or whether another, pharmacological effect was responsible for inhibition of the radiofolate uptake.

Based on the results of this study, we conclude that our DOTA-folate fulfils the preconditions for a potential therapeutic agent when combined with PMX. However, one has to critically acknowledge that PMX is a chemotherapeutic drug with anticancer activity and thus potential undesired side effects. This might be a problematic issue when PMX is solely used for kidney protection. However, it is likely that the combination of radiofolate 2 with PMX would result in an additive or synergistic effect to induce tumour regression. Corresponding experiments are currently ongoing in our laboratories. 
Acknowledgments We thank Dr. Christian Lackas and Dr. Nils Schramm for support with the NanoSPECT/CT (Bioscan).

\section{References}

1. Weitman SD, Lark RH, Coney LR, et al. Distribution of the folate receptor GP38 in normal and malignant cell lines and tissues. Cancer Res 1992;52:3396-401.

2. Garin-Chesa P, Campbell I, Saigo PE, et al. Trophoblast and ovarian cancer antigen LK26 - sensitivity and specificity in immunopathology and molecular identification as a folate-binding protein. Am J Pathol 1993;142:557-67.

3. Toffoli G, Cernigoi C, Russo A, et al. Overexpression of folate binding protein in ovarian cancers. Int J Cancer 1997;74:193-8.

4. Parker N, Turk MJ, Westrick E, et al. Folate receptor expression in carcinomas and normal tissues determined by a quantitative radioligand binding assay. Anal Biochem 2005;338:284-93.

5. Paulos CM, Turk MJ, Breur GJ, Low PS. Folate receptormediated targeting of therapeutic and imaging agents to activated macrophages in rheumatoid arthritis. Adv Drug Deliv Rev 2004;56:1205-17.

6. Guo WJ, Hinkle GH, Lee RJ. ${ }^{99 \mathrm{~m}} \mathrm{Tc}-\mathrm{HYNIC}$-folate: a novel receptor-based targeted radiopharmaceutical for tumor imaging. J Nucl Med 1999;40:1563-9.

7. Mathias CJ, Hubers D, Low PS, Green MA. Synthesis of $\left[{ }^{99 \mathrm{~m}} \mathrm{Tc}\right]$ DTPA-folate and its evaluation as a folate-receptor-targeted radiopharmaceutical. Bioconjug Chem 2000;11:253-7.

8. Leamon CP, Parker MA, Vlahov IR, et al. Synthesis and biological evaluation of EC20: a new folate-derived, ${ }^{99 \mathrm{~m}} \mathrm{Tc}-$ based radiopharmaceutical. Bioconjug Chem 2002;13:1200-10.

9. Reddy JA, Xu LC, Parker N, Vetzel M, Leamon CP. Preclinical evaluation of ${ }^{99 \mathrm{~m}} \mathrm{Tc}-\mathrm{EC} 20$ for imaging folate receptor-positive tumors. J Nucl Med 2004;45:857-66.

10. Müller C, Hohn A, Schubiger PA, Schibli R. Preclinical evaluation of novel organometallic ${ }^{99 \mathrm{~m}} \mathrm{Tc}$-folate and ${ }^{99 \mathrm{~m}} \mathrm{Tc}-$ pteroate radiotracers for folate receptor-positive tumour targeting. Eur J Nucl Med Mol Imaging 2006;33:1007-16.

11. Müller C, Schubiger PA, Schibli R. Synthesis and in vitro/in vivo evaluation of novel ${ }^{99 \mathrm{~m}} \mathrm{Tc}(\mathrm{CO})_{3}$-folates. Bioconjug $\mathrm{Chem}$ 2006; 17:797-806.

12. Siegel BA, Dehdashti F, Mutch DG, et al. Evaluation of ${ }^{111} \mathrm{In}-$ DTPA-folate as a receptor-targeted diagnostic agent for ovarian cancer: initial clinical results. J Nucl Med 2003;44:700-7.

13. Mathias CJ, Wang S, Low PS, Waters DJ, Green MA. Receptormediated targeting of ${ }^{67} \mathrm{Ga}$-deferoxamine-folate to folate-receptorpositive human KB tumor xenografts. Nucl Med Biol 1999;26:23-5.

14. Mathias CJ, Lewis MR, Reichert DE, et al. Preparation of ${ }^{66} \mathrm{Ga}-$ and ${ }^{68} \mathrm{Ga}$-labeled $\mathrm{Ga}(\mathrm{III})$-deferoxamine-folate as potential folatereceptor-targeted PET radiopharmaceuticals. Nucl Med Biol 2003;30:725-31.

15. Bettio A, Honer M, Müller C, et al. Synthesis and preclinical evaluation of a folic acid derivative labeled with ${ }^{18} \mathrm{~F}$ for PET imaging of folate receptor-positive tumors. J Nucl Med 2006;47:1153-60.

16. Ke CY, Mathias CJ, Green MA. The folate receptor as a molecular target for tumor-selective radionuclide delivery. Nucl Med Biol 2003;30:811-7.

17. Ke CY, Mathias CJ, Green MA. Folate-receptor-targeted radionuclide imaging agents. Adv Drug Deliv Rev 2004;56:1143-60.

18. Leamon CP, Reddy JA. Folate-targeted chemotherapy. Adv Drug Deliv Rev 2004;56:1127-41.

19. Gabizon A, Shmeeda H, Horowitz AT, Zalipsky S. Tumor cell targeting of liposome-entrapped drugs with phospholipid- anchored folic acid-PEG conjugates. Adv Drug Deliv Rev 2004;56:1177-92.

20. Zhao XBB, Lee RJ. Tumor-selective targeted delivery of genes and antisense oligodeoxyribonucleotides via the folate receptor. Adv Drug Deliv Rev 2004;56:1193-204.

21. Lu Y, Low PS. Immunotherapy of folate receptor-expressing tumors: review of recent advances and future prospects. J Control Release 2003;91:17-29.

22. Lu YJ, Sega E, Leamon CP, Low PS. Folate receptor-targeted immunotherapy of cancer: mechanism and therapeutic potential. Adv Drug Deliv Rev 2004;56:1161-76.

23. Leamon CP, Reddy JA, Vlahov IR, et al. Synthesis and biological evaluation of EC72: a new folate-targeted chemotherapeutic. Bioconjug Chem 2005;16:803-11.

24. Reddy JA, Westrick E, Santhapuram HK, et al. Folate receptorspecific antitumor activity of EC131, a folate-maytansinoid conjugate. Cancer Res 2007;67:6376-82.

25. Leamon CP, Reddy JA, Vlahov IR, et al. Synthesis and biological evaluation of EC140: a novel folate-targeted vinca alkaloid conjugate. Bioconjug Chem 2006;17:1226-32.

26. Reddy JA, Dorton R, Westrick E, et al. Preclinical evaluation of EC145, a folate-vinca alkaloid conjugate. Cancer Res 2007;67:4434-42.

27. Mathias CJ, Wang S, Waters DJ, et al. Indium-111-DTPA-folate as a potential folate-receptor-targeted radiopharmaceutical. J Nucl Med 1998;39:1579-85.

28. Goresky CA, Watanabe H, Johns DG. The renal excretion of folic acid. J Clin Invest 1963;42:1841-9

29. Holm J, Hansen SI, Hoiermadsen M, Bostad L. A high-affinity folate binding-protein in proximal tubule cells of human kidney. Kidney Int 1992;41:50-5.

30. McMartin KE, Morshed KM, Hazenmartin DJ, Sens DA. Folate transport and binding by cultured human proximal tubule cells. Am J Physiol 1992;263:F841-8.

31. Birn H, Spiegelstein O, Christensen EI, Finnell RH. Renal tubular reabsorption of folate mediated by folate binding protein 1 . J Am Soc Nephrol 2005;16:608-15.

32. Sandoval RM, Kennedy MD, Low PS, Molitoris BA. Uptake and trafficking of fluorescent conjugates of folic acid in intact kidney determined using intravital two-photon microscopy. Am J Physiol Cell Physiol 2004;287:C517-26.

33. Müller C, Brühlmeier M, Schubiger AP, Schibli R. Effects of antifolate drugs on the cellular uptake of radiofolates in vitro and in vivo. J Nucl Med 2006;47:2057-64.

34. Müller C, Schibli R, Krenning EP, de Jong M. Pemetrexed improves tumor selectivity of ${ }^{111}$ In-DTPA-folate in mice with folate receptor-positive ovarian cancer. J Nucl Med 2008;49:623-9.

35. Hanauske AR, Chen V, Paoletti P, Niyikiza C. Pemetrexed disodium: a novel antifolate clinically active against multiple solid tumors. Oncologist 2001;6:363-73.

36. Paz-Ares L, Bezares S, Tabernero JM, Castellanos D, CortesFunes H. Review of a promising new agent - pemetrexed disodium. Cancer 2003;97:2056-63.

37. Müller C, Schubiger PA, Schibli R. Isostructural folate conjugates radiolabeled with the matched pair ${ }^{99 \mathrm{~m}} \mathrm{Tc} /{ }^{188} \mathrm{Re}$ : a potential strategy for diagnosis and therapy of folate receptor-positive tumors. Nucl Med Biol 2007;34:595-601.

38. Müller C, Schibli R, Forrer F, Krenning EP, de Jong M. Dosedependent effects of (anti)folate preinjection on ${ }^{99 \mathrm{~m}} \mathrm{Tc}$-radiofolate uptake in tumors and kidneys. Nucl Med Biol 2007;34:603-8.

39. Kwekkeboom DJ, Bakker WH, Kooij PP, et al. $\left[{ }^{177} \mathrm{Lu}^{-D O T A}{ }^{0} \mathrm{Tyr}^{3}\right]$ octreotate: comparison with $\left[{ }^{111}\right.$ In-DTPA $\left.{ }^{0}\right]$ octreotide in patients. Eur J Nucl Med 2001;28:1319-25.

40. Teunissen JJ, Kwekkeboom DJ, Krenning EP. Quality of life in patients with gastroenteropancreatic tumors treated with $\left[{ }^{177} \mathrm{Lu}-\right.$ DOTA $^{0} \mathrm{Tyr}^{3}$ ]octreotate. J Clin Oncol 2004;22:2724-9. 
41. van Essen M, Krenning EP, Kooij PP, et al. Effects of therapy with $\left[{ }^{177} \mathrm{Lu}-\mathrm{DOTA}{ }^{0} \mathrm{Tyr}^{3}\right]$ octreotate in patients with paraganglioma, meningioma, small cell lung carcinoma, and melanoma. J Nucl Med 2006;47:1599-606.

42. Kolb HC, Finn MG, Sharpless KB. Click chemistry: diverse chemical function from a few good reactions. Angew Chem Int Ed Engl 2001;40:2004-21.

43. Kolb HC, Sharpless KB. The growing impact of click chemistry on drug discovery. Drug Discov Today 2003;8:1128-37.

44. Knör S, Modlinger A, Poethko $T$, et al. Synthesis of novel 1,4,7,10-tetraazacyclodecane-1,4,7,10-tetraacetic acid (DOTA) derivatives for chemoselective attachment to unprotected polyfunctionalized compounds. Chemistry 2007;13:6082-90.

45. Dijkgraaf I, Rijnders AY, Soede A, et al. Synthesis of DOTA-conjugated multivalent cyclic-RGD peptide dendrimers via 1,3-dipolar cycloaddition and their biological evaluation: implications for tumor targeting and tumor imaging purposes. Org Biomol Chem 2007;5:935-44.

46. Mindt TL, Muller C, Melis M, de Jong M, Schibli R. "Click-tochelate": in vitro and in vivo comparison of a ${ }^{99 \mathrm{~m}} \mathrm{Tc}(\mathrm{CO})_{3}$-labeled $\mathrm{N}_{\mathrm{t}}$-histidine folate derivative with its isostructural, clicked 1,2,3triazole analogue. Bioconjug Chem 2008;19:1689-95.

47. Rennen HJJM, van Eerd JE, Oyen WJG, et al. Effects of coligand variation on the in vivo characteristics of Tc-99m-labeled interleukin-8 in detection of infection. Bioconjug Chem 2002;13:370-7.

48. Dixon KH, Mulligan T, Chung KN, Elwood PC, Cowan KH. Effects of folate receptor expression following stable transfection into wild type and methotrexate transport-deficient ZR-75-1 human breast cancer cells. J Biol Chem 1992;267:24140-7.

49. Ladino CA, Chari RVJ, Bourret LA, Kedersha NL, Goldmacher VS. Folate-maytansinoids: target-selective drugs of low molecular weight. Int J Cancer 1997;73:859-64.

50. Mathias CJ, Wang S, Lee RJ, et al. Tumor-selective radiopharmaceutical targeting via receptor-mediated endocytosis of gallium-67deferoxamine-folate. J Nucl Med 1996;37:1003-8.

51. Forrer F, Valkema R, Bernard B, et al. In vivo radionuclide uptake quantification using a multi-pinhole SPECT system to predict renal function in small animals. Eur J Nucl Med Mol Imaging 2006;33:1214-7.

52. Müller C, Forrer F, Schibli R, Krenning EP, de Jong M. SPECT study of folate receptor-positive malignant and normal tissues in mice using a novel ${ }^{99 m}$ Tc-radiofolate. J Nucl Med 2008; 49:310-7.

53. Hammond PJ, Wade AF, Gwilliam ME, et al. Amino acid infusion blocks renal tubular uptake of an indium-labelled somatostatin analogue. Br J Cancer 1993;67:1437-9.

54. Akizawa H, Uehara T, Arano Y. Renal uptake and metabolism of radiopharmaceuticals derived from peptides and proteins. Adv Drug Deliv Rev 2008;60:1319-28.

55. Müller C, Forrer F, Bernard BF, et al. Diagnostic versus therapeutic doses of $\left[{ }^{177} \mathrm{Lu}-\mathrm{DOTA}{ }^{0} \mathrm{Tyr}^{3}\right]$-octreotate: uptake and dosimetry in somatostatin receptor-positive tumors and normal organs. Cancer Biother Radiopharm 2007;22:151-9. 